\title{
Landscapes of Illness, Politics of Segregation and Discourse of Empathy in the 19th Century Leprosy Narratives of Hawaii
}

\author{
I-Chun Wang \\ Kaohsiung Medical University and National Sun Yat-sen University
}

Follow this and additional works at: https://docs.lib.purdue.edu/clcweb

Part of the American Studies Commons, Comparative Literature Commons, Education Commons, European Languages and Societies Commons, Feminist, Gender, and Sexuality Studies Commons, Other Arts and Humanities Commons, Other Film and Media Studies Commons, Reading and Language Commons, Rhetoric and Composition Commons, Social and Behavioral Sciences Commons, Television Commons, and the Theatre and Performance Studies Commons

Dedicated to the dissemination of scholarly and professional information, Purdue University Press selects, develops, and distributes quality resources in several key subject areas for which its parent university is famous, including business, technology, health, veterinary medicine, and other selected disciplines in the humanities and sciences.

CLCWeb: Comparative Literature and Culture, the peer-reviewed, full-text, and open-access learned journal in the humanities and social sciences, publishes new scholarship following tenets of the discipline of comparative literature and the field of cultural studies designated as "comparative cultural studies." Publications in the journal are indexed in the Annual Bibliography of English Language and Literature (Chadwyck-Healey), the Arts and Humanities Citation Index (Thomson Reuters ISI), the Humanities Index (Wilson), Humanities International Complete (EBSCO), the International Bibliography of the Modern Language Association of America, and Scopus (Elsevier). The journal is affiliated with the Purdue University Press monograph series of Books in Comparative Cultural Studies. Contact: <clcweb@purdue.edu>

\section{Recommended Citation}

Wang, I-Chun. "Landscapes of Illness, Politics of Segregation and Discourse of Empathy in the 19th Century Leprosy Narratives of Hawaii." CLCWeb: Comparative Literature and Culture 20.5 (2018): <https://doi.org/10.7771/ 1481-4374.3404>

This text has been double-blind peer reviewed by $2+1$ experts in the field.

The above text, published by Purdue University Press @Purdue University, has been downloaded 109 times as of $11 /$ $07 / 19$.

This document has been made available through Purdue e-Pubs, a service of the Purdue University Libraries. Please contact epubs@purdue.edu for additional information.

This is an Open Access journal. This means that it uses a funding model that does not charge readers or their institutions for access. Readers may freely read, download, copy, distribute, print, search, or link to the full texts of articles. This journal is covered under the CC BY-NC-ND license. 


\title{
PURDUE
}

UNIVERSITY PRESS <http://www.thepress.purdue.edu>

\section{CLCWeb: Comparative Literature and Culture}

ISSN 1481-4374 <http://docs.lib.purdue.edu/clcweb> Purdue University Press @Purdue University

CLCWeb: Comparative Literature and Culture, the peer-reviewed, full-text, and open-access learned journal in the humanities and social sciences, publishes new scholarship following tenets of the discipline of comparative literature and the field of cultural studies designated as "comparative cultural studies." In addition to the publication of articles, the journal publishes review articles of scholarly books and publishes research material in its Library Series. Publications in the journal are indexed in the Annual Bibliography of English Language and Literature (ChadwyckHealey), the Arts and Humanities Citation Index (Thomson Reuters ISI), the Humanities Index (Wilson), Humanities International Complete (EBSCO), the International Bibliography of the Modern Langua-ge Association of America, and Scopus (Elsevier). The journal is affiliated with the Purdue University Press monog-raph series of Books in Comparative Cultural Studies. Contact: <clcweb@purdue.edu>

\author{
Volume 20 Issue 5 (December 2018) Article 12 \\ I-Chun Wang, \\ "Landscapes of Illness, Politics of Segregation and Discourse of Empathy in the 19th \\ Century Leprosy Narratives of Hawaii" \\ <http://docs.lib.purdue.edu/clcweb/vol20/iss5/12> \\ Contents of CLCWeb: Comparative Literature and Culture 20.5 (2018) \\ Thematic Issue Voices of Life, IIIness and Disabilities in Life Writing and Medical Narratives. \\ Ed. I-Chun Wang, Jonathan Locke Hart, Cindy Chopoidalo, and David Porter \\ <http://docs.lib.purdue.edu/clcweb/vol20/iss5/12>
}

Abstract: Leprosy is one of the oldest known human diseases, recognized throughout the world. Leprosy causes serious damage to the nervous system, often resulting in deformity in the absence of an effective treatment; sufferers were often left at the mercy of its natural process or were segregated from others due to the fear of contagion. The places ravaged by leprosy became lands of fear. Modern science has shown that leprosy bacilli have a high rate of infectivity but a rather low rate of pathogenicity, and above ninety percent of people are equipped with immunity to leprosy. Leper colonies as described in the life writings of leprosy sufferers, however, represent the politics of segregation, as well as that of fear, and pain. This paper probes into the life writings of leprosy sufferers and discusses the landscapes of illness, politics of segregation, and discourses of empathy in late nineteenth-century cultural memories of Hawaii. 


\section{I-Chun WANG}

\section{Landscapes of Illness, Politics of Segregation and Discourse of Empathy in the 19th Century Leprosy Narratives of Hawaii}

Leprosy is one of the oldest known diseases, having been witnessed in multiple locales throughout the world, including Egypt, Rome, India, and China. Leprosy often causes serious damage to nerve systems and peripheral nerves, causing deterioration of senses and corresponding abilities. Disability, disfigurement, and physical deformity caused by the disease result not only in fear of contagion but also in discrimination. Histories left behind the voices of the victims and unknown sufferers, and it is difficult to trace and document the impact of leprosy on social relations. The scattered narratives of its victims echo the effects of the disease in literature, works of art, and visitation records. This paper discusses illness, segregation, landscapes, discourses of empathy, and cultural memories in the life writings of leprosy sufferers at the turn of the century.

The Greeks borrowed the word "lepra," which Arabic physicians used for tubercular elephantiasis, for this disease (Houghton 26). The Bible describes several cases of leprosy, which refer not merely to a number of serious skin diseases but also to the social positions of the sufferers. For example, if a person develops leprosy that breaks out all over the skin and causes sores, "his dwelling should be outside the camp" (Leviticus 13: 46), away from others. Jesus, however, challenges the concept of "unclean," which suggests pollution, by restoring the "leper" to his original identity as a member of the community. However, people in medieval Europe regarded the physical deformities caused by leprosy as a punishment for their sins and the consequences were persecutory violence and expulsion. By representing the victim of leprosy as a source of fear, Dianne Neal Matthews suggests, "a diagnosis of leprosy struck fear in people's heart" (304). In the modern world, leprosy is now treatable and curable. The World Health Organization describes it as a chronic infectious disease "caused by Mycobacterium leprae, an acid-fast, rod-shaped bacillus. The disease mainly affects the skin, the peripheral nerves, mucosa of the upper respiratory tract and also the eyes, apart from some other structures. Leprosy has afflicted humanity since time immemorial" (World Health Organization). However, when leprosy affected any place, it left behind terrifying images of suffering and pain in cultural histories and human memories, and for the sufferers, it resulted in mutilation, disabilities, rejection and exclusion from the communities.

The first leprosy sufferer mentioned in Chinese history is a famous scholar and poet, Wang Can (王 粲，177-217) of the Han Dynasty (Liu 659), and the best known Chinese story involving leprosy is "Mafeng nu Qiu Li-yu" (麻瘋女邱麗玉) by Xuan Ding (宣鼎, alias Xuan Shou-mei 宣瘦梅, 128-135). This story is based on a superstition in southwestern China that leprosy could be cured only be secretly passing it on to the sufferer's spouse (128-35). Therefore, blind marriages were usually arranged for female leprosy sufferers. Jean Bodel (c. 1165-c. 1210), an Old French poet whose Chanson de Saisnes is based on the war between King Charlemagne and the Saxons, entered a leprosarium for treatment (Gray 195). In medieval English history alone, over 300 leper hospitals were documented (Roffey 203), and throughout Europe, at least 320 religious houses were established for sufferers of leprosy (Ferber 71). This phenomenon indicates not only the social landscapes of medieval Britain, but also geo-cultural concerns about what was regarded as a horrible disease. The first leprosaria in Europe, such as San Lazaro Hospital in Spain, St. Nikolai in Bardowick in Germany and Ospedale di Santa Maria della Scala in Siena, were constructed by charitable institutions in the twelfth and thirteenth centuries. Paulo Pinto points out that whenever there are significant flows and migrations of people, leprosy spread with them $(132-140)$. Although from the sixteenth century leprosy did not seem to be an endemic disease, the belief in leprosy as a scourge of God and a punishment for moral wrongs endured (Cumo 156). This stigmatization due to fear could have "hibernated in the deepest substrates of the collective European subconscious" (Ginzburg 43-45), and it was widely accepted in medieval and early modern Europe and carried on until the nineteenth and twentieth centuries. During the medieval period, the number of leper asylums was not fewer than twenty thousand in France only (Liveing 278), but before the mid-twentieth century, almost all accounts refer to leprosy sufferers as outcasts from society. Leprosy became a "construct" disease, "invented by those in power to secure their political, cultural, and economic dominance" (Watts 7), and leprosy victims were mostly banished from their own communities. According to Peter L. Allen, the Middle Ages were a time of cruelty for many: thieves, outlaws, and political criminals were hanged, buried alive, beaten to death, or used as spectacles, and in some cases, leper houses were even allowed to burn down with the inhabitants still inside (39). Leprosy settlements, 
dating to the early modern period, remained places of segregation well into the nineteenth century. For example, between 1844 and 1849, the government of New Brunswick, Canada passed legislation that was intended to prevent the spread of infectious diseases, and about 150 people were segregated on Sheldrake Island by health officials (Heagerty 463). In the 1890s, a leper colony was established in the United States in Carville, Louisiana. Other leper colonies from around the world include Culion in the Philippines, the Island of Spinalonga in Greece, Abu Zaabal in Egypt, Naung Kan in Myanmar/Burma, Kano in Nigeria, and Chacachacare, an island in the Republic of Trinidad and Tobago. Although incidences of leprosy have declined because of modern medicine, leprosy continued to be associated with cultural and social stigma, anxiety, memories of unprepared migration, isolation, and systems of institutionalization. The social landscapes of leprosy also signify geopolitical boundaries between 'the norm' and 'the unclean,' as constructed by human networks.

The nineteenth century was not only an era of self-revelation and exploration, but also of exploitation, expansion of power. As Michel Foucault points out, confinement and quarantine were often used as punitive practices. Foucault refers punitive practices used in asylums as "reticent" physical penalties; it means that although one does not touch the body, the penal systems directly affected the body and especially to the life of the confined person. They "deprive the individual of a liberty that is regarded both as a right and as property. The body, according to this penality, is caught up in a system of constraints and privations, obligations and prohibitions" (11). Exploration and expansion result in an imperialistic model of diseases as threatening, and of further arbitrary management skills, such as segregation and quarantine, that define a certain ethnic group as inferior (Snelders 4-5). Subgenres of life writing such as illness narratives and witness literature that emerged during the nineteenth century do not merely reveal the culturally constructed fear of diseases, but also uncover the endeavors of missionaries whose empathetic discourse penetrates into a world forgotten by the ordinary world. Among illness narratives and witness literature, however, life writing about leprosy displays the most distressful part of human life and the least communicable suffering and pain, because leprosy sufferers are regarded as sinners. Once segregated, they could not bear their original names for various reasons, and only in very rare cases could they have the chance to see their families again. In IIIness as Metaphor, Susan Sontag says, "Any disease that is treated as a mystery and acutely enough feared will be felt to be morally, if not literally, contagious" (6). Though she compares cancer to a "demonic enemy," she admits that leprosy was among the diseases that had caused "deepest dread" in medieval Europe (58), but in cultural history, nothing brings more fear and infliction than a disease like leprosy. Since Roman times, leprosy had been seen as a social stigma, and the victims of leprosy were often called the living dead. During the Middle Ages and the Renaissance, leprosy sufferers were either pushed to the outskirts of towns and cities or became the focus of people's hostile gaze (Mullaney 32). Due to the lack of an effective cure, most victims of leprosy suffered from deformities and were mostly left at the mercy of natural processes or were segregated from the community. The places ravaged by leprosy became lands of fear.

The apparatus of persecution did, however, contribute to a collective identity for the sufferers. Modern science has proved that leprosy bacilli have a high infectivity rate but a rather low pathogenicity (McMenamin 7), and approximately ninety-five percent of people have a strong enough immune system to resist the infection (Scollard et al. 354). Leper colonies around the world, however, represent an important issue for cultural anthropology and landscape memories. The past two decades have seen the rediscovery and publication of various life writings of leprosy sufferers, such as Who Walk Alone, by Perry Burguess, In the Sanctuary of Outcasts: A Memoir by Neil White, Out of the Shadow of Leprosy by Claire Manes and Marcia Gaudet, Squint: My Journey with Leprosy by Jose P. Ramirez, Jr. and No Footprints in the Sand: A Memoir of Kalaupapa by Henry Nalaielua and Sally-Jo Keala-O-Anuenue Bowman. Each of these expresses the personal and collective memories of the sufferers and the settlements in which they lived, giving words to their pain and describing landscapes of fear. Their life writings also form discourses of empathy and manifestations of forgotten chapters of human history.

The bulk of this article discusses the cultural history of the leper colony of Kalaupapa on the island of Molokai, Hawaii, probably best known from the writings by and about Father Damien (alias Jozef De Veuster, 1840-89) and Jonatana Napela (1813-79). It focuses on the life writings of Father Damien, a Roman Catholic priest from Belgium whose letters were collected by his brother Father Pamphile, and Peter Young Kaeo (1836-80), a Hawaiian high chief and politician of the Kingdom of Hawaii, who was exiled to Kalaupapa in 1873 after being diagnosed with leprosy. Although both Kaeo and Damien narrate leprosy and its effects on people and their environment from different perspectives, their concerns for the sufferers reflect the calamities that Haiwaii encountered in the nineteenth century. 
Father Damien was one of the Catholic priests working at the Kalaupapa leprosy settlement. The original leper colony was first established in Kalawao, but in 1863, King Kamehameha $V$ of Hawaii signed an act to prevent the spread of leprosy to the United States by isolating those who were infected in Kalaupapa Peninsula; this had the result of separating the sick from the "normal" and the sufferers from their families. Even those who were suspected of having leprosy were forced by law to remain for the rest of their lives in this secluded place. The hope behind this policy was to help the sufferers; however, as Damien describes, this "wretched state of bodily and spiritual misfortune has often made my heart bleed within [me]" ("Father" 822). Damien arrived in Kalawao, where a rigorous segregation policy was enacted, in 1873. The settlement on Kalaupapa at which Damien provided help accommodated about eighty thousand people, with shelters built of old pendanus groves and castor-oil trees (Father Pamphile 89). When he arrived at Molokai, there were about two thousand leprosy victims, approximately eight hundred of whom were still living on Molokai. He learned carpentry and became the settlement's undertaker and gravedigger as well as its pastor, since half of the residents were Catholic while a large number of them were Anglicans. Damien began his routine by visiting the sufferers and hearing confessions, and eventually took himself "as a leper with the lepers" in order to understand their needs (93). During the years when Damien worked on the island, there were about twenty priests scattered over various locations. Damien was not perfect; he kept his own little cottage as his own and hired a cook, but he understood that during the night, he was "the sole keeper of the garden of the dead" in this area of Molokai (118). In this environment marked by fear, sickness, and a large number of deaths, there was no doctor in residence for several months; as Damien said in his letters, this place was designed for the banished, not for a doctor's skill (115-118), and the tears and wailings of the leprosy victims created a pitiable atmosphere.

In his letters, Damien observes that the progression of the disease began with discolored patches on the skin and loss of feeling. This discoloration spreads to the whole body, and "then ulcers begin to open, chiefly at the extremities. The flesh is eaten away, and gives out a fetid odor" (Father Pamphile 92). At first, he needed to use tobacco to ease the atmosphere or run outside to breathe fresh air (88), but his pity for the helpless and unfortunate sufferers isolated to this corner of the island between "inaccessible cliffs and sea" (91) led him to eventually identify himself as a leper (92-95). In a letter dated November 23, 1871, he wrote to his brother, Father Pamphile: "My dear brother-God has deigned to choose your unworthy brother to assist the poor people attacked by that terrible malady...this plague has been spreading in the islands" and the Government shut up "these unfortunate creatures are condemned to perpetual exile" in the corner of the island of Molokai (92).

In The Landscape of Fear, Yi-fu Tuan notes that people everywhere expect order and reconciliation (6-7). He defines fearsome landscapes with imagery of darkness, abandonment, anxiety in a strange settings, epidemic diseases, devastating wars, and various kinds of calamities (3). Tuan finds many types of fearsome landscapes in human history, ranging from hostile forces to deadly epidemics that struck big cities, such as the plagues in Messina and London, cholera in Moscow (101-3), and Yellow fever in Philadelphia. For Tuan, the order in the human world is transient, while natural calamities, famines, droughts, and floods not only represent the hostility of the environment, but also the anxieties from which people suffer. The landscape of fear caused by disease, however, is often involved with social construction; during the late nineteenth century, a period of expansion of imperialism, the cultural construct of diseases was associated with power relations and social factors. As J. N. Hays observes, the extension of trade and transportation routes during the mid-nineteenth century, and the imposition of economic control over less developed areas not only caused "larger social and economic dislocations" (181), but also created a drastic effect on disease patterns and on unequal treatment, as many leper colonies operated under systems of segregation.

The opening of various digital archives has made available more stories and life writings of the nursing sisters and priests who, with little knowledge of the disease, risked their lives to stay with and look after the sufferers. In his letters, Damien notes that when surrounded by poor lepers, he wished to multiply himself in order to alleviate their suffering and their loneliness (Father Pamphile 96). He appreciated Father André Nolander, Père Wendelin and three Franciscan sisters of Christian Charity coming to his assistance, although the shifting of missionary helpers was frequent. Damien's discourse of empathy is exemplified in his construction of himself as a leper and a comforter. The Hawaiian government's annual budget for the settlement was based on weekly portions of meat and taro (97). The alms sent by benefactors then helped procure little comforts for the sick, and bundles of clothes arrived from time to time from the Superioress of the Sisters in Honolulu and the Procurators in Paris. Regent Liliuokalani (1838-1917), the last monarch of Hawaii, visited the leper settlement at Kalaupapa 
on Molokai in 1881. She was too overwhelmed to speak during a ceremony and "John Makini Kapena, one of her brother's ministers, had to address the people on her behalf" ("Lili'uokalani"). She assigned Damien as Knight Commander of the Royal Order of Kalakaua, and he was commissioned to construct a hospital.

Suzanne Keen defines empathy as a "vicarious, spontaneous sharing affect" (207). The discrepancies between the stigmatization of leprosy and the discourse of empathy in the nineteenth century society were insurmountable, particularly in Hawaii, a place in which rampant leprosy had only recently begun. As Damien observes, "Death had brought down the number of patients to about five hundred, but now the government is sending new ones by dozens every week" (Father Pamphile 142). Damien's letters are similar to another life writing dealing with leprosy, Perry Burgess's Who Walk Alone, about a soldier who contracted the disease and was not allowed to go home after the end of the Spanish-American War in 1898. Upon his arrival at Culion Island, he finds a child sent to this leper colony is always by himself; later, he witnesses relatives of the sufferers visiting their families could watch them, with dried tears, from a boat.

Damien's empathetic disposition is evident in his persistent devotion to the colony. He was deeply moved by the devoted Christians on the island; once, as he held the Blessed Sacrament, he was followed by a long line of lepers, some deprived of hands, others of feet, crawling on their knees, in the great act of adoration. After he risked going to another island, he received an official notice "informing him that if he attempted to leave, or even visited any other portion of the island, he would be put under immediate arrest" (Father Pamphile 90). Damien died in 1889 after sixteen years of service on the island, during which he bathed lepers, built churches, dug graves, fixed water pipes, and built coffins. In 1886, he himself contracted the disease, with whose symptoms he was familiar; he told his congregation the news by using the phrase "we lepers," though even before this, many of them regarded him as an empathetic other. In a letter to his Bishop, Mgr. Koeckmann, he wrote, "I cannot come to Honolulu, for leprosy has attacked me... I shall soon be quite disfigured. As I have no doubt of the real character of the malady, I remain calm, resigned, and very happy in the midst of my people" (Father Pamphile 133). The Bishop himself refers to Damien as a man who, with heroic devotion, voluntarily exiled himself at Molokai and had been attacked by the disease that would never relax the sufferer until death came (133). His letter of November 25, 1885, included the phrase "Fiat voluntas tua," or "thy will be done" (133), and in a letter probably sent later, he had confirmed the Hawaiian Government had commissioned him to build a large hospital for several hundred lepers. When visited by Father Colomban Beissel, he said he never lost courage nor tried to leave the island; as long as the disease had not distorted his hands, he would continue to say Mass. Damien's discourse of empathy to the lepers connotes empatheia, the Greek equivalent of Einfühlung, or "in-feeling" (Depew 100). As he stood at the altar providing services for those who need guidance of God, he knew he was drawn towards the grave ("Father Pamphile" 146).

Peter Kaeo was a leprosy sufferer from the royal family of the Hawaiian Kingdom. In 1873, the same year in which Father Damien arrived, he was exiled to Kalaupapa. Kaeo was thirty-seven years old, while Damien was thirty-three, and each of them represented their experiences as witnesses, victims, and devotees with empathy in the land of fear and suffering.

There were no records of the time when Kaeo contracted leprosy; however, both Kaeo and Damien arrived at Kalaupapa during a time when Hawaii was undergoing a crisis under the waves of imperialism. As Alfons L. Korn indicates in the introductory chapter of News from Molokai: Letters between Peter Kaeo and Queen Emma 1873-1876, Kaeo became a victim of leprosy in the 1860s. Queen Emma (18361885) was queen consort of King Kamehameha IV (1834-1863), and was respected for her humanitarian work. The correspondence between Emma and Kaeo reveals not only the landscape of illness but also the political crisis during the last three decades of the nineteenth century. Emma's father George Naea (? -1854) contracted leprosy, and she ordered the establishment of a general hospital in Honolulu for the benefit of all Hawaiians and especially those with leprosy. When Kaeo was exiled, King Kamehameha V, Emma's brother-in-law, attempted to reverse this decision, but Kaeo was still among the first to be sent to Molokai (Korn, News 7). Emma tried to run for royal election in 1874 but failed, because Kalākaua (1836 - 1891; reigned from 1874 to 1891) was favored; this led to riots, about which Kaeo expressed concerns, as he learned the people involved were arrested for treason (Korn, News 223).

Kaeo stayed at Kalaupapa for three years and was eventually released from the settlement; he returned to Honolulu, where he died in 1880. In a time in which leprosy was regarded with abhorrence, Kaeo's correspondence with Queen Emma established his identity as a leprosy sufferer, a member of 
the royal family, a loyal citizen and subject of the Kingdom of Hawaii, and an insightful advisor for Hawaii's national policy. The 122 letters between Peter Kaeo and Queen Emma that Korn collects in his anthology are authentic life writings that serve as sources not only for the historiography of disease in the Kingdom of Hawaii, but also for Hawaii's treaty with the United States and rivalries among the countries with which it traded. Kaeo's correspondence displays empathy for the distressed people in Kalaupapa and his honesty and dignity in advising Emma about the policy of his home country as well as the areas that were coveted by colonial powers. As he heard of the possible release of leprosy victims from Kalaupapa, he raised the question: "[S]hould Queen Emma allow all of us to return to our homes, thus allowing this disease to spread, why, it would be the ruination of the Hawaiian Nation and perhaps the whole world" (241-242). His comments, based on his first-hand knowledge of leprosy, prioritized the economic situation and public health of Hawaii:

It would immediately stop our Commerce, no Foreign Vessels will touch our ports for fear of the disease. All the foreign Powers who we are in treaty with will not sanction this Act of Queen Emma's, and what would be the consequence....Queen Emma will be the cause of the death of Thousands. I for my part would be willing to remain here I have saved some Io's and oukou [all of you] some Hundreds who would be sure to catch it should we be allowed to return....(Korn, News 242)

In a letter to Kaeo, Queen Emma noted that several ministers were "wickedly desperate" to force the King to sign a treaty ceding Pauuloa to the USA (Korn, News 15). Kaeo expressed the importance of the kingdom's subjectivity with regard to trade relationships and unequal treaties. According to Korn, most American missionaries, sugar planters, and merchants supported annexation, but three-fourths of the native Hawaiians were opposed to the control of foreign powers (xiii).

Hawaii was annexed by the United States in 1898, though the Reciprocity Treaty of 1875, which High Chief Kalākaua (1836-1891) signed when he ascended to the throne, gave the United States market free access to sugar and other products. Though the merchant settlers brought prosperity, the indigenous people were displaced, reinforcing the notion of "white rule as the only means of establishing order and morality in the islands" (Vann). For example, Walter M. Gibson, President of the Board of Health, even reminded that the Hawaiian people should remold themselves from barbarism in order to construct health $(41 ; 49-50 ; 90-91)$. Unsurprisingly, the next few decades saw the deportation and mass segregation of Hawaiian leprosy sufferers.

Kenneth R. Conklin characterized the racial separatism in the politics of the Kingdom of Hawaii between 1874 and 1902 as "Hawaiian apartheid" (120-130). Gavan Daws contends that the politics of the time mostly involved segregation, since those sent to the peninsula as leprosy suffers were "overwhelmingly Hawaiian or part-Hawaiian commoners" while the Europeans who contracted the disease, though small in number, "were able to buy their way out of the hands of the examining physician and leave the islands" (71). Especially when leprosy was associated with the native, Hawaii's annexation with the United States became a catalyst for reinforcing segregation policy. According to Conklin, Hawaii was often under the gaze of her neighboring power, with the United States as her chief trading partner. Eventually a joint resolution was passed in 1898, and Hawaii became an annexed territory of the United States (1-25).

Peter Kaeo's letters express the anxiety of the people who lived in the caves of the hills in Kalaupapa, whose anxiety grew as they heard the rumors that even the doctors were becoming sick, the Board of Health resigned (Korn, News 197), and they would have all their horses killed. They therefore chose to hide themselves in caves during the daytime and came out only during the night. Kaeo found among them some without fingers and some without feet (24). He also observed death scenes such as that of a man who was buried rolled up in a blanket, those of people who could barely walk (29), and those of people afraid of the desolation of winter. Kaeo describes the geography of Kalaupapa and feels sympathy for those who were too weak to resist the wind from the gorge of the mountains. The misery caused by the winter wind at Kalaupapa was characterized as striking, shaking, muttering, whistling, and howling, and the people could only wait quietly for the coming of morning. Thanks to his position, Kaeo was able to request examinations from the Hospital at Kalawao for the people on the island (48).

Endemic leprosy narratives in different countries reveal different cultural and political effects on the environment and social phenomena. During his three years at Kalaupapa, Kaeo did his best for the sufferers on the island in particular. He requested medical support, food, and clothing for the sickly poor. In his letter dated August 13, 1873, he reported that a doctor named Dr. Trousseau arrived to examine those whose conditions were curable (Korn, News 53-54) while those who needed more examination were sent to Honolulu (293) However, Kaeo's perspective as both a leprosy sufferer and a 
member of the royal family draws attention both to the segregation in this landscape of pain and fear and to the politics within the kingdom and the relationship between Hawaii and the imperial powers. As Korn points out in his annotation of Kaeo's letters, his life as a leprosy victim was even "complicated by his cousin's ambition to achieve the Kamehameha throne" (278) while the United States was increasingly exerting its power on Hawaii. When the leprosy sufferers looked to Kaeo as a revolutionary figure, William Phileppus Ragsdale (c. 1837-1877) assembled people to prevent a possible mutiny (Tayman 109).

From 1866 to 1969, Kalaupapa housed thousands of leprosy sufferers. During the three years when Kaeo stayed in the settlement, Father Damien and Peter Kaeo did not interact much due to their distinct religious identities, but their life writings share their experiences as leprosy victims and as witnesses of the suffering caused by leprosy. They both observed and sought to help those who lacked warm clothing or medical care; Kaeo asked his cousin Queen Emma for further supplies, while Damien asked for help from other missionary groups. Kaeo would ride to the beach to meet the new arrivals or walk up to the mountains to check on the people hiding themselves out of fear, and Damien would say rosaries, conduct Masses, comfort the dying at their bedsides, construct cottages and a church, and help dig in the graveyard. They both envisioned better medical care on Kalaupapa, but such care was very limited during their lifetimes. Perry Burgess (1886-1962), American preacher and founding member and president of the Leonard Wood Memorial for the Eradication of Leprosy, also satirized in his pseudobiographical narrative, Who Walk Alone: "We, the banished, were to be welcomed to the company of the banished," (101) since in the nineteenth century there were no modern facilities for leprosy sufferers. However, Father Damien had plunged himself into the company of leprosy sufferers when there was not much assistance. Kaili'ohe Kame'ekua, a leprosy victim at Kalaupapa, said in her oral history, "Watching him [Damien] I learned about Jesus" (qtd. in Law 95), and Peter Kaeo took his obligation from his sympathy toward others afflicted with leprosy.

Theodor Lipps (1851-1914) relates empathy to core human values and aesthetic experiences. Following Lipps, Jean Decety states that empathy is a natural capacity to "share, understand and respond with care to the affective states of others" ("Introduction" vii); it also plays a role in our aesthetic appreciation of objects. Dan Zahavi relates empathy to Husserl's and Merleau-Ponty's understanding of intersubjectivity. As Zahavi contends, observation and imagination are crucial to the content and quality of the experience of empathy, and empathy does not dissolve the boundaries between self and other because empathy is the "experience of the embodied mind of the other" (151). As they learned to empathize with the sick and the poor, Peter Kaeo humbled himself by seeking supplies of food and medical care instead of representing himself as an important political figure, while Damien constructed himself as an extraordinary moral supporter and a spiritual guide by crossing the border between self and other.

\section{Works Cited}

Allen, Peter L. The Wages of Sin: Sex and Disease, Past and Present. U of Chicago P, 2000.

Burgess, Perry. Who Walk Alone. Henry Holt, 1940.

Conklin, Kenneth R. Hawaiian Apartheid: Racial Separatism and Ethnic Nationalism in the Aloha. E-BookTime, 2007.

Cumo, Christopher Martin. The Ongoing Columbian Exchange: Stories of Biological and Economic Transfer in World History. ABC-Clio, 2015.

Daws, Gaven. Holy Man: Father Damien of Molokai. U of Hawaii P, 1973.

Decety, Jean. "Introduction: Why Empathy is so Important." Empathy: From Bench to Bedside, edited by Jean Decety, MIT Press, 2012, vii-ix.

Depew, David. "Empathy, Psychology and Aesthetics: Reflections on a Repair Concept." Poroi: An Interdisciplinary Journal of Rhetorical Analysis and Invention, vol. 4, no. 1, 2005, pp. 98-107.

"Father Damien's Detachment." The Spectator, 15 June 1889, pp. 821-3.

Father Pamphile, editor. Life and Letters of Father Damien, the Apostle of Lepers. The Catholic Truth Society, 1889.

Foucault, Michael. Discipline and Punish: The Birth of the Prison. Translated by Alan Sheridan, Vintage, 1995.

Gibson, Walter Murray. Sanitary Instructions for Hawaiians in the English and Hawaiian Languages. Honolulu: P.C. Advertiser, 1881.

Ginzburg, Carlo. "Leprosos, judeus, muçulmanos." História noturna. Companhia das Letras. 2007, pp. 43-67.

Gray, Douglas. Robert Henryson. Brill, 1979.

Hays, Jo. N. The Burdens of Disease: Epidemics and Human Response in Western History. Rutgers UP, 2009.

Heagerty, John Joseph. "Leprosy in Canada." International Journal of Leprosy and Other Mycobacterial Diseases, vol. 1 , no.4, 1933, pp. 463-468. 
CLCWeb: Comparative Literature and Culture 20.5 (2018): <http://docs.lib.purdue.edu/clcweb/vol20/iss5/12>

Special Issue Voices of Life, IIIness and Disabilities in Life Writing and Medical Narratives. Ed. I-Chun Wang, Jonathan Locke Hart, Cindy Chopoidalo, and David Porter

Houghton, James. The Cyclopædia of Practical Medicine: Comprising Treatises on the Nature and Treatment of Diseases, Materia Medica and Therapeutics, Medical Jurisprudence, etc. Volume 3, edited by Sir John Forbes, Alexander Tweedie and John Conolly. Sherwood, 1834, pp. 26-34.

Keen, Suzanne. "A Theory of Narrative Empathy." Narrative, vol. 14, no. 3, 2006, pp. 207-36.

Korn, Alfons L., editor. News from Molokai: Letters between Peter Kaeo and Queen Emma 1873-1876. U of Hawaii P, 1976.

---. "Introduction." News from Molokai: Letters between Peter Kaeo and Queen Emma 1873-1876. U of Hawaii P, 1976, pp. xi-xlv.

Law, Anwei Skinsnes. Kalaupapa: A Collective Memory. U of Hawaii P, 2012.

"Lili'uokalani." Wikipedia, en.wikipedia.org/wiki/Lili\%CA\%BBuokalani. Accessed 15 June 2018.

Lipps, Theodore. "Empathy, Inner Imitation, and Sense Feelings." A Modern Book of Aesthetics, edited by Melvin Rader. Holt, Rinehart and Winston, fifth edition, 1979, pp. 371-378.

Liu, Yue-Jin (刘跃进). 秦漢文學编年史 (A Chronicle History of Literature of Qin and Han Dynasties). Shang Wu, 2006.

Liveing, Robert. "Abstract of the Goulstonian Lectures on Elephantiasis Graecorum Delivered at the Royal College of Physicians, 1873." British Medical Journal, vol. 1, 1873, pp. 277-81.

Manes, Claires and Marcia Gaudet. Out of the Shadow of Leprosy. U of Missouri P, 2013.

Matthews, Dianne Neal. The One Year Women of the Bible. Tyndale House Publishers, 2007.

McMenamin, Dorothy. Leprosy and Stigma in the South Pacific: A Region-by-Region History with First Person Accounts. McFarland \& Company, 2011.

Mullaney, Steven. The Place of the Stage: License, Play and Power in Renaissance England. U of Michigan P, 1988.

Nalaielua, Henry and Sally-Jo Keala-O-Anuenue Bowman. No Footprints in the Sand: A Memoir of Kalaupapa. Watermark Publishing, 2006.

Pinto, Paulo Gabriel Hilu da Rocha. O estigma do pecado: a lepra durante a Idade Média. Physis, vol. 5, no. 1, 1995, pp. 132-144.

Ramirez, José, Jr. Squint: My Journey with Leprosy. UP of Mississippi, 2009.

Roffey, Simon. "Medieval Leper Hospitals in England: An Archeological Perspective." Medieval Archaeology, vol. 56, 2012, pp. 203-233.

Snelders, Stephen. Leprosy and Colonialism: Suriname under Dutch Rule, 1750-1950. Manchester UP, 2017.

Scollard, D. M., L. B. Adams, T. P. Gillis, J. L. Krahenbuhl, R. W. Truman, and D. L. Williams. "The Continuing Challenges of Leprosy." Clinical Microbiology Reviews, vol. 19, no .2, 2006, pp. 338-81.

Sontag, Susan. Illness as Metaphor. Farrar, Strauss and Giroux, 1978.

Stein, Edith. On the Problem of Empathy: The Collected Works of Edith Stein, vol. 3. 1917. Translated by Waltraut Stein. The Institute of Carmelite Studies, 1989.

Tayman, John. The Colony: The Harrowing True Story of the Exiles of Molokai. Scribner, 2006.

Tuan, Yi-fu. Landscape of Fear. U of Minnesota P, 2013.

Watts, Sheldon. Epidemics and History: Disease, Power, and Imperialism. Yale UP, 1997.

Vann, Michael G. "Contesting Cultures and Defying Dependency: Migration, Nationalism, and Identity in Late Nineteenth-Century Hawaii." Stanford Electronic Humanities Review, 1997, web.stanford.edu/group/SHR/52/vann.html.

World Health Organization. "Leprosy Elimination." World Health Organization, http://www.who.int/lep/leprosy/en/.

Xuan, Ding (宣鼎; 宣瘦梅). 麻瘋女所麗玉 ("Ma feng nu Qiu Liyu"). 夜雨秋燈錄 (Ye yu qiu deng lu). 古籍出版社 (Classics Publishing House), 1987, pp. 128-135.

Zahavi, Dan. Self and Other: Exploring Subjectivity, Empathy and Shame. Oxford UP, 2014.

Author's profile: I-Chun Wang teaches general education, English literature and language courses at National Sun Yat-sen University and Kaohsiung Medical University in Taiwan. She was Dean of the College of Humanities and Social Sciences at KMU and Dean of College of Liberal Arts at National Sun Yat-sen University. She has published, edited and co-edited books and special issues in Canadian Review of Comparative Literature (ACCL), CLCWEB Journal, and Cultura and published book chapters in Cultural Discourse in Taiwan (NSYSU), Landscape, Seascape and Ecological Imagination (Routledge), and Asia and the Historical Imagination (Palgrave Macmillan). E-mail: icwang@mail.nsysu.edu.tw; ichunwang@kmu.edu.tw 